\title{
A Methodological Approach to Selective Cutbacks*
}

\author{
CHARLES H. BÉLANGER and LISE TREMBLAY†
}

\begin{abstract}
At times - when budget must be severely reduced on short notice and when serisible decisions must arise from complex situations - planners have to work out simple but reliable measures of resource allocation and reduction. This paper recognizes the need for applied research in this area and proposes a budget reduction formula that has the advantage of relating financial planning to program evaluation, faculty resources, and activity levels of departmental units. The tool developed is flexible, as it can be manipulated without endangering its basic assumptions to describe best each unit's intrinsic characteristics. Futhermore, its redistributive effects can be readily measured and made to respond to institutional priorities.
\end{abstract}

\section{RÉSUMÉ}

Lorsque les budgets doivent être réduits rapidement de façon substantielle et que des décisions acceptables doivent être prises à partir de situations compliquées, les planificateurs et gestionnaires ont besoin de s'appuyer sur des approches simples et fiables d'allocation et de réduction de ressources. Cet article reconnait la nécessité de la recherche appliquée dans ce domaine et propose une formule de réduction budgétaire qui a l'avantage d'établir la relation entre la planification financière et l'évaluation des programmes, les ressources professorales et les activités d'enseignement des unités académiques. La flexibilité de l'instrument permet de respecter les caractéristiques disciplinaires de chaque unité. De plus, les résultats de l'application de la méthodologie donne la possibilité d'évaluer rapidement les effets redistributifs des réductions budgétaires et d'y porterunjugement à la lumière des priorités institutionnelles.

\footnotetext{
* The views expressed do not necessarily reflect those of the Office of Institutional Research. The authors wish to acknowledge the valuable contribution of all COPER members whose ideas constituted the essence of this paper.

$\dagger$ Bureau de recherche institutionnelle, Université de Montréal.
} 
Budget cuts have become less and less a news item as postsecondary institutions around the world have increasingly become targets of local and national governments trying to patch up faltering economies. In a survey of European universities conducted by the Organization for Economic Cooperation and Development (OECD), participating institutions were unanimous in deploring both the regression of consumable financial means and the budget decline, worsened by an overporportional increase in personnel costs (Bender and Henning, 1980). At the United Kingdom's forty-five universities, some administrators, in the spring of 1981, were privately toying with the idea of asking faculty members to take voluntary pay cuts to avoid massive layoffs (Walker, 1981). The situation was not less severe in North American institutions. Many American legislatures had forced universities to operate with huge deficits and to declare a state of financial emergency (Magarrell, 1981; Watkins, 1981). Canadian provincial and federal governments also were being accused of having added colleges and universities to their "hit list" (Winter, 1981).

In the Province of Quebec alone, the balance sheets of the six universities were expected to show a $\$ 60$-million reduction in the total $\$ 816$-million university grant by the end of May 1982 (Imbeault, 1981). That austerity in higher education spending was only the beginning of a long-term plan to reduce expenditures in the public sector. In 1981, the Quebec government unveiled a triennial plan for the financing of its universities, according to which, the Universite de Montréal can anticipate a \$45-million deficit between 1982 and 1985 (Carbonneau, 1981). That news came after the university had already imposed substantial horizontal reductions for the fiscal year 1981-82.

\section{SELECTING A COURSE OF ACTION}

Confronted with a critical situation, Universite de Montréal officials took the position that the quality of academic programs and the vitality of the institution, to say nothing of its solvency, could no longer be saveguarded by continuing to make across-the-board compressions of its 200-million operating budget in order to erase a $\$ 15$-million annual average deficit during three consecutive years. These officials had to decide whether everybody would starve or someone would be thrown overboard. Two committees were established and mandated to examine both the academic units and the administrative units and to make recommendations to the University Planning Committee (UPC) by October 1981. Both committees completed their work on schedule and submitted their reports to the UPC for discussion and approval before presenting them to appropriate authorities. As could be expected, many options - termination of academic and nonacademic positions, deletion of services, voluntary pay cuts, early retirements with built-in incentives, protection of tenured positions on a part-time basis, and numerous others - were seriously considered in the course of deliberations of both task forces.

The study of instructional units included detailed scrutiny of all degree programs (COPER, 1981). The general objective was to reduce teaching resources by use 
of the following means: (1) reducing course offerings, (2) reducing section breakdowns, (3) eliminating courses with low enrolment, (4) promoting cyclical course offerings, (5) increasing section sizes, (6) raising discontinuance questions on low productivity programs, and (7) making more efficient use of teaching resources.

There are no universal program evaluation formulae that could fit all institutions. The combination of teaching methods (lecture, laboratory, practicum), the mix of disciplines, the degree program structures, internal capabilities, external needs and constraints, the historical context of each unit, and the institutional mission itself produce unique patterns. These factors and others have received extensive coverage in the literature, especially in the light of some rather dramatic institutional experiences (Shirley \& Volkwein, 1978; Smith, 1980; Herman, 1982). In addition, a number of authors have spelled out the difficulties and modi operandi involved in program discontinuance (Brewer, 1978; Davis \& Dougherty, 1979; Dougherty, 1981; Melchiori, 1981).

Where program reviews are done in the context bordering financial exigency planning, institutions have a particularly difficult task in reconciling budgetary, programmatic, and personnel considerations to produce rapid results (Moore, 1978). Despite these critical retrenchment pressures, universities must find ways to reallocate resources to growing fields such as computing and biotechnology (Mims, 1980) and to revitalize and retrain their instructional staff (Calhoun et al., 1980; Fleming, 1980). It was with that awareness, but not necessarily with full understanding of the obstacles that laid down, that the task force members went about the business of recommending reductions of course offerings and teaching personnel.

\section{METHODOLOGY}

Before becoming involved with the technicalities of the approach, it is important to note (1) that most bachelor's degrees (with the exception of a few professional ones) comprise widely heterogeneous proportions of compulsory, optional, and elective courses amounting to 90 credits; and (2) that most professional programs in the health sciences area were evaluated on a basis substantially different (student-faculty ratio) from that presented below.

Essentially, the methodology was based on a normalization procedure which sought to estimate the course credit offerings that any given unit ought to offer taking the following factors into account: (1) its existing undergraduate degree program structures, (2) the average number of students in sections, (3) teaching resources, (4) other obligations such as service courses, (5) disciplinary characteristics, and (6) protection of graduate programs (Table 1).

The determination of course credit offerings is done through the normalization formula in which the compulsory, service.courses and other specific teaching commitments are considered essential to the integrity of departmental programs and interdisciplinary teaching activities. Alternatively, optional course offerings are revised, if necessary, to take into account student clienteles and group partitioning. 


\section{$\triangle$ TEACHING RESOURCES}

FTE* Career Faculty Members

FTE Part-Time Instructors

Total FTE Teaching Staff

$\triangle$ DEGREE PROGRAM STRUCTURE (UNDERGRADUATE)

\begin{tabular}{|c|c|c|c|c|}
\hline & COMPULSORY & OPTIONAL & ELECTIVE & TOTAL CREDITS \\
\hline Bachelor's & 21 & $60(15)^{\star \star \star}$ & 9 & 90 \\
\hline Major & $21^{\star \star \star}$ & $33^{* \star \star}$ & 6 & 60 \\
\hline Minor & $3^{\star \star \star}$ & 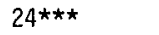 & 3 & 30 \\
\hline
\end{tabular}

$\triangle$ INSTRUCTIONAL DATA

Course Credits Taught (Undergraduate) 225

Section Credits Taught (Undergraduate) 236

Average Section Size (Undergraduate) 37

Course Credits Taught (Graduate) 51

Service Course Credits 21

SCHs* (Teaching)/Tota I FTE Teaching Staff (Teaching productivity) 323

SCHs (Tutoring)/FTE Career Faculty Members (Tutoring productivity) 63

* FTE $=$ Full-Time Equivalent Staff (average teaching load of 12 credits).

SCH $=$ Student Credit Hour.

** The number in () indicates that a minimum of 15 optional credits out of a total of 60 must be taken outside the discipline.

$\star \star \star$ These are already included in the bachelor's credit offerings.

The normalization formula can be expressed as follows:

$$
\mathrm{NC}=\mathrm{CC}(1)+\mathrm{OC}(\mathrm{x})+\mathrm{SC}(1)+\mathrm{PC}(1)
$$

where $\mathrm{NC}$ are the normalized course credit offerings

$\mathrm{CC}$ are the compulsory course credit offerings

$\mathrm{OC}$ are the optional course credit offerings

SC are the service course credit offerings

PC are the credits from protected activities

$\mathrm{x}$ is the normalization factor varying from 1.5 to 3 
The normalization factor is applied differentially to all credits offered by a given unit in a single year. A factor of 1 is applied to compulsory, service and protected course credits in order to ensure the safeguard of these teaching activities (Table 2a). For all other credit offerings, the normalization is set to a value determined from section size and kept constant for all units (Table 2b). The schedule and magnitude of the factors attributed to the various section sizes have been determined through simulations of varying student and program characteristics, keeping in mind two major objectives. One was to enable even the smallest department to preserve the integrity of its program(s) and some level of specialization in allowing for a reasonable spectrum of optional courses. The other was to build within the factors, incentives for the units to teach freshman and service courses to large classes, and to use group partitioning more discriminantly.

\section{ANALYSIS}

The analytical scheme was intended to reduce, on a selective basis, the current level of resources. For a typical degree program structure, it consisted of the following five steps: (1) presentation of basic data, (2) normalization of credit offerings, (3) reduction of credits and full-time equivalent teaching staff (FTEs), (4) verification of teaching resources vs. normalized credits, and (5) recommendations. An application of that methodology for a selected department is presented in Tables 1 through $3 \mathrm{~b}$. Table 1 gives a brief overview of actual teaching resources, degree programs and their structures, and various raw products and productivity factors related to instructional data. Table 2 a shows how the degree program credits of the various categories are multiplied by a factor to arrive at a number of normalized credits. The recommended reduction of credits and FTEs (Table $3 a)$ is derived from a direct subtraction of actual course credits taught from normalized course credits. The verification of teaching resources is a necessary step taken to check whether the department could meet the demands of the normalized number of course credits with its reduced teaching credit potential. With the example used in this presentation, one can observe (Table $3 \mathrm{~b}$ ) that the department could still maneuver with a margin of 19 credits, assuming it chose to offer the same number of graduate credits. Therefore, the final step of the process was to recommend: (1) a reduction of 44 optional credits, (2) a reduction of 3.7 FTEs, (3) an increased student-credit-hour (SCH) productivity, and (4) a sustained effort in research.

The methodology which has just been described is a standardized approach designed to relate program offerings, faculty resources, and institutional budgetary reduction requirements. The premises leading to its development were simple: it has to relate to the teaching and programmatic activities of departments; it had to take into account the teaching resources required to sustain a sufficient level of activities; and finally, it had to be developed quickly. The assumption that current program structures and course offerings were adequate, if not optimal, in attaining each department's educational goals was the basis for the rationalization of course offerings and faculty resources that would take place through the application of this methodology. 
TABLE $2 a$

Normalization of Credit Offerings

\begin{tabular}{|l|c|c|c|}
\hline Categories of Credits & $\begin{array}{c}\text { Number of Degree } \\
\text { Program Credits }\end{array}$ & $\begin{array}{c}\text { Multiplication } \\
\text { Factor }\end{array}$ & $\begin{array}{c}\text { Normalized } \\
\text { Credits }\end{array}$ \\
\hline Compulsory Courses & 21 & 1.0 & 21 \\
Optional Courses & 45 & 2.3 & 104 \\
Service Courses & 27 & 1.0 & 21 \\
Protected Credits & 35 & 1.0 & 35 \\
\hline TOTAL & & & 181 \\
\hline
\end{tabular}

* The factor is 1.0 except for optional credits. See Table 2b.

** Refer to introduction courses that have to be broken down in sections

TABLE $2 b$

Normalization Factor Used for Optional Courses

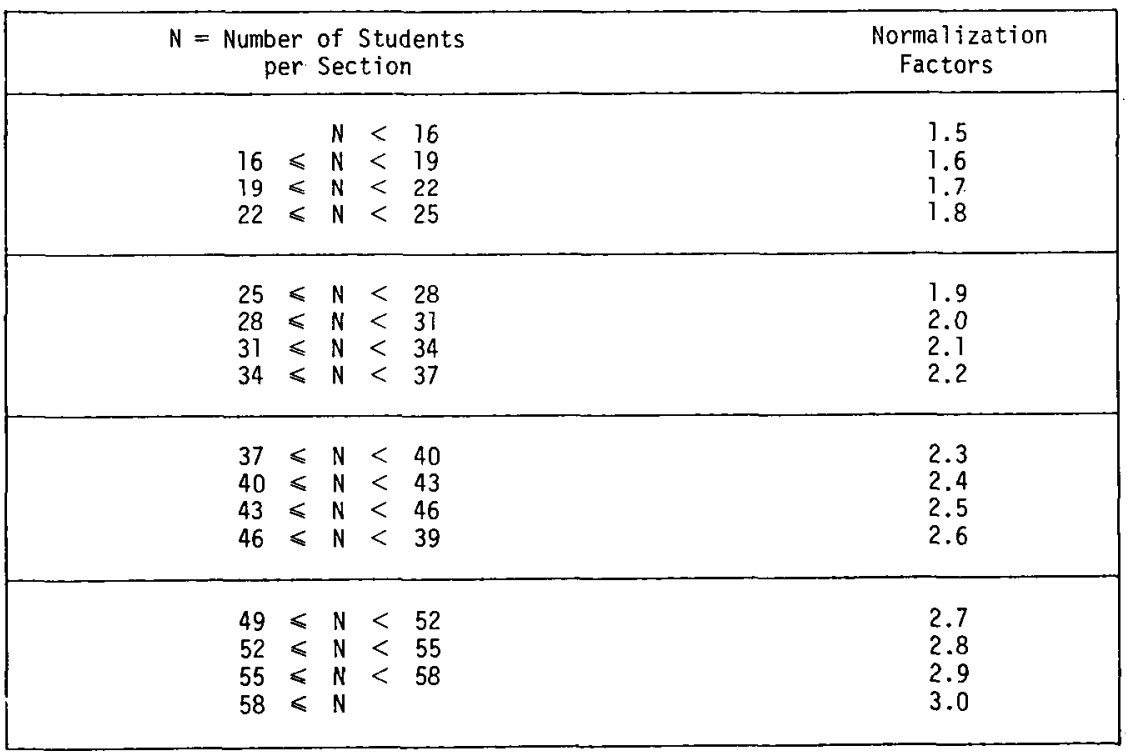

Although strong arguments can be put forth to defend the merits of this approach, the results must be analyzed in a more comprehensive planning perspective. To this end, we have performed two types of analysis. In the first, we examined how the parameters used in the reduction formula related to one another and to other variables describing departmental teaching activities and how the level of proposed reduction related to these indicators of activities and resources. In the second, we analyzed the reduction pattern to determine whether a substantial reorganization of teaching resources had been taking place among 
units and across disciplinary lines and whether newer and smaller programs had been more affected by the reductions than larger and longer established ones.

\section{RESULTS OF THE ANALYSIS}

The evaluation of the relative influence of the reduction formula variables and of other related variables was undertaken through correlation analyses. Pearson product-moment correlation coefficients were used to measure the strength of the relationships between different variables describing the activities and resources of the 38 academic departments. These variables included program structure (measured by the number of compulsory, optional, and elective courses contained in each department's undergraduate programs), average section size, course credit offerings, faculty size and composition, and teaching productivity (measured by the ratio SCH/FTE). Next, partial correlation coefficients provided a measure of association between pairs of variables of the analysis while controlling the effect of one or more related variables. This second analysis was particularly useful in characterizing the relationships between the reduction levels calculated by the application of the formula and the variables of activity and resources described above.

Results from the Pearson correlation analysis (Table $4 \mathrm{a}$ ) show that the reduction proposals were significantly but weakly linked to average section size $(-.45)$, to undergraduate course credits taught (.32), and to teaching productivity $(-.36)$. The relationships with the variable productivity in particular shows that the overall level of activity and resources of departments was a relevant factor in the proposed level of reduction. However, there were no significant relationships between reduction levels and faculty composition or between the structure of course offerings and the proportion of optional courses relative to the total program structure of the department.

The partial correlation analysis which was performed on different combinations of variables with the level of reduction as a dependent variable also showed the variable productivity and its correlates to be significant controlling factors in the analysis (Table $4 \mathrm{~b}$ ).

The correlation analyses have conclusively established that the greater the level of teaching activity and, indirectly, teaching resources a department had, the less reduction in activity and resources it had to assume. The use of a multiplication factor based on "section size" to determine the optional credit offerings for optional courses can, thus, be said to have indirectly introduced into the reduction procedure the criteria of performance and attraction of programs. Furthermore, the findings did not confirm the main criticism which some department heads had voiced against the methodology - that the larger the proportion of optional course credits in a department's program structure, the smaller the reduction this department would have to support.

The second analysis, aimed at evaluating the distributional impact of the reduction methodology, used the Spearman rank-correlation coefficient. The 38 departments were rank ordered according to their levels of teaching resources 
TABLE 3a

Reduction of Credits and FTES

Course Credits Taught (Undergraduate)

Course Credits Normalized (Undergraduate)

Reduced Number of Credits

Reduced Number of FTEs $\left(44 \div 12^{\star}\right)$

* 12 credits = Average Teaching Load per FTE

Note: Graduate credits were not used in the above normalization formula since they were all protected as is.

TABLE 3b

Verification of Teaching Resources vs. Normalized Credits

- IEACHING RESOURCES BEFORE NORMALIZATION

FTE Career Faculty Members

22.0

Estimated Sabbatical Leaves*

- IEACHING RESOURCES AFTER NORMALIZATION

Residual FTE Career Faculty Members

Residual Total FTE:

(19.4 FTE CFM** + 5.7 FTE PTI**) - 3.7 FTES 21.4

- VERIFICATION OF TEACHING POTENTIAL

Teaching Credit Potential:

21.4 FTEs $\times 12$ (Average Teaching Load)

Normalized Course Credits:

181 (Undergraduate) +51 (Graduate)***

Course Credits Taught (1980-81):

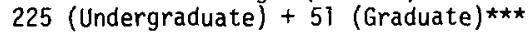

Section Credits Taught (1980-81):

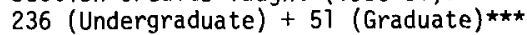

287

* One out of 7 tenured faculty members is estimated to be on leave every year.

** $\quad$ CFM $=$ Career Faculty Member; PTI: Part-Time Instructor.

*** Graduate credits were all protected.

before and after the reduction procedure was applied (Table 5). The results of the correlation analysis $\left(\mathrm{r}_{\mathrm{s}}=.983, \mathrm{p}<.01\right)$ showed that the relative distribution of departments was not significantly affected by the application of the methodology and that a significant realignment of resources would not take place. However, an analysis of percentage point differences in FTE teaching resources indicated a wide disparity among units in the level of reduction which ranges from 0 to $30.6 \%$ from previous levels. The disciplinary areas most affected by reductions were languages and, to a lesser extent, some pure and applied sciences such as physics, chemistry, mathematics, and geology. In these instances, section size was related to laboratory activities embedded in the program structure of 
33 A Methodological Approach to Selective Cutbacks

TABLE $4 a$

Correlation of Selected Variables of Teaching Activities and Resources

\begin{tabular}{|lcc|}
\hline & $\begin{array}{c}\text { Productivity } \\
\text { SCHs/FTE }\end{array}$ & $\begin{array}{c}\text { Credit reduction } \\
\text { proposals }\end{array}$ \\
\hline Optional course credit offerings & $.314^{\star \star}$ & \\
FTE career faculty members & $.447^{\star \star}$ & \\
FTE faculty staff & $.420^{\star \star}$ & \\
Average section size & $.832^{\star \star}$ & $-.045^{\star \star}$ \\
Undergraduate credits taught & $.370^{\star \star}$ & $.320^{\star}$ \\
Credit reduction proposals & $-.369^{\star \star}$ & \\
\hline
\end{tabular}

* $\mathrm{p}<.05 ; \quad$ * $\mathrm{p}<.01 ; \quad \mathrm{n}=38$

TABLE 4b

Partial Correlation between Credit Reductions and Selected Variables ${ }^{\star \star \star}$

\begin{tabular}{|c|c|c|}
\hline First-order partials & Second-order partials & Third-order partials \\
\hline $\begin{array}{c}\text { CREDIT REDUCTION WITH } \\
\text { AVERAGE SECTION SIZE } \\
\text { BY }\end{array}$ & $\begin{array}{c}\text { CREDIT REDUCTION WITH } \\
\text { AVERAGE CLASS SIZE } \\
\text { BY }\end{array}$ & $\begin{array}{l}\text { CREDIT REDUCTION WITH } \\
\text { AVERAGE SECTION SIZE } \\
\text { BY }\end{array}$ \\
\hline $\begin{array}{ll}\text { VAR } & 1 \\
\text { VAR } 2 \\
\text { VAR } 3\end{array}$ & $\begin{array}{ll}\text { VAR } 1 \text { and VAR } & 3 \\
\text { VAR } 2 \text { and VAR } 3 \\
\text { VAR } 1 \text { and VAR } 2\end{array}$ & VAR 1 and VAR 2 and VAR 3 \\
\hline $\begin{array}{ll}-.281 & P=.045 \\
-.470 & P=.002 \\
-.529 & P=.001\end{array}$ & $\begin{array}{ll}-.133 & P=.219 \\
-.437 & P=.004 \\
-.291 & P=.042\end{array}$ & -.001 \\
\hline
\end{tabular}

$\star \star \star$ VAR $1=$ SCHs/Total FTE teaching staff;

VAR 3 = Undergraduate credits taught

VAR 2 = Total FTE teaching staff;

these departments. Furthermore, most of them had been experiencing for some years decreasing levels of student enrolment and, consequently, of teaching productivity. These two factors (the mix of teaching activities and low productivity) may have worked together to target these units for major reductions.

The more traditional and longer established departments - such as sociology, philosophy, economics, psychology, and others in the arts and humanities - have been assured of resource reductions of $5 \%$ or less from past levels because of their program structures, high levels of teaching productivity, and large average section sizes. Among the newer programs, those in the field of languages, for example, have been hit very hard. Other new programs of the same size - communication science, demography, and library science - have fared well. Again, teaching productivity seems to have been a determining factor in discriminating among older and newer programs. 
ductivity seems to have been a determining factor in discriminating among older and newer programs.

\section{CONCLUSION}

In recent years, program review has been associated very closely with retrenchment and program discontinuance. The review process itself has become a long and cumbersome operation in which questions of authority, definition of institutional priorities, and search for consensus rarely have been resolved to the satisfaction of everyone involved. Other considerations often overlooked by the initiators of the review have been the time lags necessary to complete a wide range of studies and the human and financial costs that have been generated by comprehensive and multidimensional review operations.

While there is a need for continued study of program review procedures in which quantitative and qualitative indicators can be assembled and appraised by appropriate bodies, most institutions have neither the time nor the resources to perform them at a university-wide level. Therefore, methodologies such as the one developed for the Université de Montréal can become valuable planning tools by providing the first directions for program evaluation, for allocation of resources, and, most importantly, for reexamination of institutional priorities.

The program review formula implemented at the Universite de Montréal has, in effect, proven to be useful in more than one respect. Despite its limited scope, the implemented formula has allowed for the introduction of criteria such as needs, institutional priorities, and general performance. For instance, when reductions in teaching resources were being considered, the nature of the teaching resources at stake was independently evaluated with respect to tenure: status, research productivity, and complementarily to other departmental resources this in addition to the verification in teaching capacity performed within the methodology itself.

Another important result of this operation has been the insight that the methodology has provided on two long-standing issues of program evaluation: the appropriate size of optional course offerings and the match between instructional activities and the teaching resources required to sustain them. With respect to the first point, the methodology suggests linking optional course offerings to student attendance, group partitioning, and productivity. The criteria of need and efficiency are thus considered for the definition of the appropriate threshold level. As for matching instructional activities to teaching resources, the calculated course offerings baseline can be used to indicate the most desirable level of resources which can be equated to the unit level of activity.

A final and not less significant impact of the review process has been to create a situation whereby units are beginning to question their own modes of operation, their use of faculty resources, and their instructional activities. Efficiency, performance, and quality criteria are thus progressively considered as important departmental priorities. There is hope that self-evaluation will lead to self-imposed reallocation of resources and to the necessary changes in departmental organization. 


\section{REFERENCES}

Bender, I. \& Henning, W. Survey of the state-of-the-art and likely future trends of university management in Europe - Austria, Germany, and the Netherlands. Paris: OECD (Organization for Economic Cooperation and Development): Centre for Educational Research and Innovation, 1980.

Brewer, G.D. Termination: Hard choices - Harder questions. Public Administration Review, $1978,38(4), 338-344$.

Calhoun, L.G. \& Macfarlane, J.B. Faculty exchange in psychology: Faculty development without most of the costs. Teaching of Psychology, 1980, 7 (2), 111-112.

Carbonneau, R. L'université devra effectuer des compressions budgétaires de $\$ 45,000,000.00$ d'ici 1985. Forum - Université de Montréal, 1981, 16 (5), 1.

COPER: Comité sur les priorités - Secteurs: Enseignement et recherche. Montréal: Vicerectorat à la planification, Université de Montréal, 1981.

Davis, C.K. \& Dougherty, E.A. Guidelines for program discontinuance. Educational Record, $1979,60(1), 68-77$.

Dougherty, E.A. Should you starve all programs or eliminate a few? In S.R. Hample (Ed.), Coping with faculty reduction, New Directions for Institutional Research,(No.30). San Francisco: Jossey-Bass Inc., 1981.

Fleming, T. Beyond survival: Policies for academic revitalization in an uncertain environment. Canadian Journal of Higher Education, 1980, 10 (2), 103-115.

Herman, R. Universities: Survival of the fattest. New Scientist, 1982, pp. 360-363.

Imbeault, M.A. La coupure exigée est trop brusque. Affaires universitairesÜniversity Affairs, octobre 1981, pp. 4-5.

Magarrell, J. Budget cuts in some states arouse fears of new layoffs of professors. The Chronicle of Higher Education, 1981, 23 (5), pp. 1; 10.

Melchiori, G.S. De l'inertie à l'initiative: Comment faire face à la modification des programmes universitaires. Revue internationale de gestion des établissements d'enseignement supérieur, 1981, 5 (2), 153-163.

Mims, S. Resource reallocation: Stopgap or support for academic planning. In R.B. Heydinger (Ed.), Academic Planning for the 1980s, New Directions for Institutional Research (No. 28). San Francisco: Jossey-Bass Inc., 1980.

Moore, M.A. On launching into exigency planning. Journal of Higher Education, 1978, 49 (6), 620-638.

Shirley, R.C. \& Volkwein, J.F. Establishing academic program priorities. Journal of Higher Education, 1978, 49 (5), 472-488.

Smith, D.K. Multi-campus system approaches to academic program evaluation. In E.C.Craven (Ed.), Academic Program Evaluation, New Directions for Institutional Research (No. 27). San Francisco: Jossey-Bass Inc., 1980.

Walker, D. To avoid layoffs, British universities may ask professors to take pay cuts. The Chronicle of Higher Education, 1981, 23 (1), 26.

Watkins, B.T. Michigan State's budget cut 13.5 million; 368, many with tenure, face loss of jobs. The Chronicle of Higher Education, 1981, 23 (8), pp. 1; 8-9.

Winter, M. The crisis in universities. Maclean's, 1981, 94 (45), 58-68. 